\title{
PLANTS OF THE FAPNING AND RANCHING AREAS OF THE CANADIAN PRAIRIES
}

This book, by Arch $\ddot{C}$. Budd, who has contributed so generously to our Botany section each. issue, is on the press at the present time and will be ready for distribution shortly. Besides the flowering plants, Ferns and. Fern Allies and Gymnosperms have been included. The book is well illustrated by many of $\mathrm{Mr}$. Budd's drawings, as well as over fifty photographs taken by him.

Not before has so extensivo a study been publishod about western wild flowers. Judging from a preview of the original manuscript, we have no hesitancy in recommending this book to all who are interested in knowing moro about our flora.

\section{INDIAN PIPES:}

On Saturday, May 13, William MacNeil, Forestur at Meadow Lake, noted several clusters of Indian Pipes (Monotropa Uniflora) on Section I, Township 54, Range 17, West of 3rd. The clusters were last year's growth and were growing under a dense stand of fifty-year old Jackpine.

Will other members be on the look-out for this interesting plant and report any finds.

\section{NATIONAI WIIDLIFE CONSERVATION DIGEST}

This is a new Nature magazine, published at 127 Ruby Street, Winnipeg. Volume I, No. I, was printed in January.. It is published monthly. The Digest contains Nature articles, and discusses conservation problems covering the North American continent. In it, the reader will find articles of lasting interest for the Nature lover and the sportsman.

We have received the first three numbers, and are very pleased with them. Here is a Canadian publication, worthy of the support of every naturalist. The subscription rate is $\$ 3.00$ a year.

\section{THE HARBINGER OF SPRING HAS HISTORIO PAST}

By Cliff Shaw, Yorkton

(Publishod April 20, in the Western Producer)

"Before the end of April the warm sunshine will have unrolled a carpet of lavender crocusos across the prairies and in every mural school, boys and girls will vie with each other to be first in bringing a blossom to tho teacher's desk.

Perhaps no flower on the prairies is more welcome than the first crocus. And although they are in no way related to the true crocus it is doubtful if they will ever be widely known on the prairies by any other name.

. If you have tried to transplant the prairie crocuses you will havo noticed that they grow from a sturdy taproot rather than from a bulb as does the true crocus. Instead they belong to a large plant family which 